Brit. J. Psychiat. (1979), 134, 547-52

\title{
Correspondence
}

\section{CYGLES IN THE CARE OF THE INSANE}

\section{DeAr Sir,}

I should like to offer some observations on Patricia Allderidge's admirable Squibb Lecture (Journal, April 1979, 134, 321-34).

Miss Allderidge has convincingly demonstrated how false is the notion, still widespread and copied from book to book, of 'demoniacal possession' as having been the universal explanation of mental disorder up to the seventeenth or even the eighteenth century. She has shown that mental illness was provided for and treated-whether medically or by religious means-as other illnesses. She has pointed out the important distinction between 'demoniacal possession' and disease (of any kind) said to be caused by devils-or, she might have added, by witchcraft. She has given fresh examples of how the mentally afflicted were given 'relief' under the Poor Lawpractices which were first brought to light by $\mathrm{Dr} A$. Fessler in 1956; and for the first time she has shown us how the Common Law of England governed what might and what might not be done in a case of mental disorder, long before there was any specific legislation.

Miss Allderidge has also mentioned the strange case of Mary Lamb, who never had to stand trial for the murder of her mother. It seems so unlikely that this should have been a unique instance of leniency, or rather of the law turning a blind eye on a crime because of the offender's mental state-yet no one has so far been able to find a parallel case. Surely further research is needed to solve this mystery. Incidentally, Miss Allderidge has not ventured to name Mary's place of confinement; I am pretty certain that it was Fisher House in Essex Road, Islington, which was at the time licensed to a Mrs Ann Holmes.

On one point Miss Allderidge has-I think unfortunately-followed the 'received version' which elsewhere she has so vigorously disputed. This is where she repeats the cliche that the Lunacy Act of 1890 hamstrung any real advance for seventy years. Now the Act, in spite of its bulk, made only two changes of any consequence: it imposed a Magistrate's order for the detention of private patients (which had long since been required for 'paupers'), and it required the recertification of detained patients at stated intervals. The objections our predecessors raised were, firstly, that the Magistrate's order inflicted a stigma which would deter the patient's family from seeking in-patient care for him; and, secondly, that no provision was made for voluntary admission to public asylums. The assumption in both cases was that early admission was beneficial, or even essential, to recovery. This belief was based entirely on the simple finding that more recoveries occurred among patients whose illness was of recent onset; but this finding could and probably did mean only that mental disorders of acute onset have a better natural prognosis than those with a more insidious course. There is no reason to suppose that in those years the early admission to an asylum of, say, a case of slowly progressing schizophrenia could have been of any benefit.

Voluntary admission had been allowed to licensed houses and registered hospitals since the $1860 \mathrm{~s}$ and was actually made easier by the 1890 Act, but the facility was little used before the First World War, and does not seem to have made any notable impact.

There was nothing in the Lunacy Act to prevent the treatment of uncertifiable cases in nursing homes, general hospitals or special clinics, or as out-patients. The painfully slow development of such provision had many causes-voluntary hospitals were indifferent to the need or lacking in resources, and Poor Law authorities were too restricted in their powers-but the want of progress cannot be blamed on to ' 1890 '.

8 Avenue St Nicholas (Flat 1),

Alexander Walk

Harpenden, Herts.

\section{EPILETIC HOMICIDE: DRUG-INDUGED}

Dear Str,

I have read with interest the case report and commentary by John Gunn (Journal, May 1978, 132, 510-13) and the consequent correspondence (Colin Brewer, August 1978, 133, 188; Bartholomew et al and Gunn, December 1978, 133, 564-5). John Gunn refers to the proposal of the Butler Committee (Home Office/DHSS, 1975) that the uncertainty between non-insane automatism and insanity should be clarified by reformulating the special verdict of 'not 
guilty by reason of mental disorder', thus allowing a sentencing Court discretion in disposal. This would avoid such a verdict resulting automatically in the detention in hospital of the accused at the direction of the Secretary of State for an unlimited period of time. Gunn goes on to describe mental disorder as including those conditions at present defined as insanity and embracing all forms of automatism except those transient states caused by drugs, alcohol, or physical injury. It is with this in mind that the following case report is considered of interest.

A single man aged 35 , the elder of two children attacked his widowed mother, aged 71 , late on the evening of February 11, 1978. The mother received serious facial injuries and some few weeks later died of a pulmonary embolism. The accused was initially seen in custody on March 11, charged with inflicting grievous bodily harm-but later with murder-and could give an accurate and detailed account of his behaviour over the weeks preceding the assault, and similarly details of his behaviour up to 10.30 p.m. on the night of the assault; but he had no clear recollection of events from then on until his mind cleared some few days later whilst in custody.

Witness statements described how the victim sent for her neighbour about 10.30 p.m. because the accused was behaving oddly, and this was later confirmed by the neighbour, who stated that the accused was unable to recognize him. The neighbour sought help and while he was absent from the house the assault took place. The arresting police officers found the accused calm but bewildered.

He had previously received psychiatric treatment as both in-patient and out-patient over many years, with diagnoses of depression or of inadequacy, and he had both threatened suicide and taken overdoses on several occasions. There had been no suggestion at any time that he had suffered from epilepsy. Over many years he had taken Mandrax (methaqualone and diphenhydramine) and latterly was receiving lorazepam $2.5 \mathrm{mg}$ and maprotiline $75 \mathrm{mg}$, both three times per day and Mandrax 2 tablets at night.

The possibility of organic cerebral dysfunction as a cause for an aggressive act in a man said to be nonaggressive and known to have no previous criminal record led to an electroencephalographic study. Within the right temporal lobe there were regular high-voltage slow waves during the slow phase, and during the fast phase spike ard spike-and-wave activity occurred, consistent with the presence of a right temporal lobe epilepsy of indefinite but probably long duration, without overt seizures except perhaps at the time of the offence. Tricyclic drugs, including maprotiline can produce epilepsy (Shepherd, 1978, B.M.J., ii, 10 June, 1523 and Adverse
Reaction Information Service 1976. C.S.M. FO6, p. 140).

Counsel for the accused decided on the defence of automatism, and in legal argument before $\mathrm{Mr}$ Justice $\mathrm{R}$. Smith defined automatism as a lack of mens rea due to some failure of the mind not caused by disease, accepting that failure of the mind caused by disease comes within the McNaughton rules. This argument was essentially based on the decision of the Court of Appeal in R. v. Quick (1973) 3 A., E.R. 347the case of a diabetic committing an assault during a hypoglycaemic episode following an injection of insulin. It was held that the malfunctioning of his mind had not been caused by his diabetes but by the use of insulin prescribed by his own doctor. Lord Justice Lawton said (at page 356) "Our task has been to decide what the law means now by the words 'disease of the mind'. In our judgement the fundamental concept is of a malfunctioning of the mind caused by disease. A malfunctioning of the mind of transitory effect caused by the application to the body of some external factor such as violence, drugs including anaesthetics, alcohol, and hypnotic influences cannot fairly be said to be due to disease. Such malfunctioning unlike that caused by a defect of reason from disease of the mind will not always relieve an accused from criminal responsibility. A self-induced incapacity will not excuse nor will one which could have reasonably been foreseen as a result of either doing or omitting to do something, as for example, taking alcohol against medical advice after using certain prescribed drugs, or failing to have regular meals whilst taking insulin".

The defence, therefore, argued that the malfunctioning of the mind of the accused was caused not by his epilepsy but by the taking of maprotiline in accordance with his doctor's prescription. The Crown offered no medical evidence and His Lordship directed the jury to acquit the accused.

While in custody no medication was exhibited, but since acquittal and for the following four months the patient has received carbamazepine in a dosage controlled by serum levels, and serial EEG recordings have shown a progressive improvement in pattern of rhythm. At no time since the offence has there been evidence of overt epilepsy. It must be rare to find a case with a defence of automatism based on malfunctioning of the mind rather than disease of the mind leading to acquittal.

H. B. Milne

Waddiloves Hospital, Queens Road, Bradford BD $7 B T$ 